\title{
Pendidikan Berbasis Agama Islam Sebagai Katalisator Di Lingkungan Sosial Perkotaan
}

\author{
Abdul Aziz Muslimin \\ Universitas Muhammadiyah Makassar \\ Aziz-sniper@yahoo.com
}

\begin{abstract}
ABSTRAK
Pendidikan Islam hendaknya dapat mewarnai kepribadian seserorang, sehingga agama benar-benar manjadi bagian dari pribadinya dikemudian hari. Agama harus dihayati benar dan digunakan sebagai pedoman hidup manusia, maka agama harus menjadi dasar dalam kepribadiannya. Pendidikan Islam harus menyentuh tiga institusi pendidikan yaitu keluarga, sekolah dan masyarakat. Jangan dikesankan bahwa tugas pendidikan hanya tugas guru di sekolah ataupun dosen di kampus, bahkan pendidikan keagamaan (tata cara shalat, mandi hadas besar, dan lain-lain) dikesankan tugas ustadz ataupun guru agama di sekolah/kampus. Orangtua harus senantiasa membentengi keluarga dengan pendidikan keagamaan dan jangan ragu untuk mem-back up anakanaknya sekolah di lembaga pendidikan keagamaan seperti madrasah ataupun pesantren. Perkembangan/pembentukan kepribadian anak tidaklah terjadi dengan begitu saja, melainkan merupakan perpaduan (interaksi) antara faktor-faktor konstitusi biologi, psikoedukatif, psiko-sosial dan spiritual. Anak akan tumbuh dan berkembang dengan baik bilamana diasuh dan dibesarkan dalam lingkungan keluarga yang sehat dan bahagia. Keteladanan dalam pendidikan merupakan metode influentif yang paling meyakinkan keberhasilannya dalam menyiapkan dan membentuk anak pada moral, spiritual dan sosial. Realitas kehidupan di perkotaan sudah sangat terkontaminasi dengan pengaruh pragmatism dan hedonisme, sehingga dengan bekal Pendidikan Islam dari tiga lingkungan pendidikan dapat menjadi katalisator diri untuk berinteraksi dalam menyelami kehidupan sosial di perkotaan. Bahkan modernisasi sudah merasuki semua sendi-sendi kehidupan sosial manusia, sehingga terkesan dunia ini tanpa batas lagi, dan hanya dengan Pendidikan Agama Islam yang mejadi "pegangan" sehingga seseorang mampu membentengi diri atau terlibat jauh dengan kehidupan bebas di perkotaan.
\end{abstract}

Kata Kunci: Pendidikan Islam, Katalisator, Kehidupan Perkotaan.

\section{PENDAHULUAN}

UU Guru dan Dosen No. 14 tahun 2005 tentang Guru dan dosen yang sangat menekankan agar kompotensi guru dan dosen harus lebih tinggi dari jenjang pendidikan yang di ampuhnya. Tujuan pendidikan meliputi perubahan dalam tiga bidang yaitu kognitif (pengetahuan), afektif (sikap), dan psikomotorik (keterampilan). Agar tujuan ini dapat tercapai maka strategi pelaksanaan pendidikan perlu diatur dan direncanakan semaksimal dan seefektif mungkin, bahkan diperlukan adanya pendidikan yang profesional pada semua level pendidikan. 
Sebagai pendidik yang sehari-hari mengajar, tentunya tidak jarang harus menangani peserta didik yang mengalami kesulitan dalam belajar. Hal ini terkadang membuat guru frustasi memikirkan bagaimana menghadapi anak-anak seperti ini. Demikian juga para orangtua yang memiliki anak yang mempunyai kesulitan dalam belajar. Akan tetapi yang lebih menyedihkan adalah perlakuan yang diterima anak yang mengalami kesulitan belajar dari orangtua ataupun guru yang tidak mengetahui masalah yang sebenarnya, sehingga memberikan label kepada anak-anak mereka sebagai anak yang bodoh, tolol, ataupun gagal.

Masyarakat menempatkan guru ataupun pendidik pada tempat yang lebih terhormat di lingkungannya, karena dari sosok pendidik yang profesional dan amanah dalam melakoni profesinya, diharapkan sistem pendidikan berjalan baik untuk memperoleh out put pendidikan yang berkemajuan. Hal ini berarti bahwa guru dan dosen sebagai pendidik berkewajiban mencerdasakan kehidupan bangsa menuju pembentukan manusia Indonesia yang seutuhnya berdasarkan cita-cita luhur bangsa Indonesia.

Weber dalam Soekanto (1985:44) mengemukakan bahwa substansi dua teori di atas menekankan bahwa tindakan-tindakan yang berupa usaha untuk menarik perhatian orang, sebenarnya merupakan sebuah tindakan sosial yaitu suatu tindakan yang nyata diarahkan kepada orang lain. Adapun tindakan sosial itu adalah langkah konkret yang merupakan tindakan manusia yang menurut si aktor mengandung makna subyektif yang menjadi tindakan-tindakan nyata.

Tugas dan peran pendidik tidaklah terbatas dalam masyarakat, bahkan guru pada hakekatnya merupakan komponen strategi yang memiliki peran penting dalam menentukan gerak maju kehidupan bangsa. Keberadaan guru bagi suatu bangsa amatlah penting, terlebih lagi bagi bangsa yang sedang membangun. Di tengah-tengah lintasan perjalanann zaman dengan teknologi yang kian canggih dari segala perubahan dan pergeseran nilai.

Profesi guru banyak dibicarakan orang, bahkan terkadang sebagian informasi tersebut cenderung melecehkan posisi guru baik yang sifatnya menyangkut kepentingan umum sampai kepada hal-hal yang bersifat pribadi, sedangkan dari pihak guru sendiri nyaris tak memberikan perlawanan ataupun pembelaan. Sebagian masyarakat menilai bahkan menuding guru tidak berkompeten, tidak berkualitas, bilamana tak dapat menyelesaikan persoalan yang dihadapinya sendiri atau tidak memiliki kemampuan tersendiri. 
Besarnya harapan dan keinginan para orangtua akan kecerdasan anaknya, melahirkan antusiasme dan kepedulian terhadap setiap kegiatan dalam upaya pencerdasan yang diperlukan bagi anak-anaknya. Pendidikan tidak hanya dipandang sebagai usaha pemberian informasi dan pembentukan keterampilan saja, namun diperluas sehingga mencakup usaha untuk mewujudkan keinginan, kebutuhan dan kemampuan individu sehingga tercapai pola hidup pribadi dan sosial yang memuaskan.

Namun, realitas konsep sektarian beranggapan bahwa tugas pendidikan atau pencerdasan anak hanya merupakan tugas para guru dan institusi pendidikan, pembinaan keagamaan (mengaji, shalat dan ibadah lainnya) merupakan tugas guru agama di sekolah dan ustadz di masjid/TPA. Di sisi lain, para orangtua hanya berada di wilayah konsumtif, yaitu penyediaan sandang, pangan dan papan. Bahkan pada masyarakat perkotaan, modernisasi dan globalisasi telah meruntuhkan semua "kaidah-kaidah" orangtua dahulu.

St. Vembriarto (1990:39-40) menguraikan bahwa masyarakat telah mengalami perubahan fungsi-fungsi sosial keluarga seperti:

1. Fungsi pendidikan, dahulu keluarga merupakan satu-satunya "institusi pendidikan", walau belum ada sekolah formal tapi anak-anak patuh dan cerdas. Realitas sekarang, secara formal fungsi pendidikan "telah diambil" sekolah dengan segala dinamikanya.

2. Fungsi Rekreasi, dengan perkembangan kota yang begitu pesat dan hadirnya tempat hiburan telah menggeser keluarga sebagai media rekreasi. Keluarga hanya dikesankan tempat persinggahan dan urusan rekreasi bisa di luar rumah.

3. Fungsi keagamaan, tadinya keluarga tempat penggemblengan keagamaan, namun pragmatisme sebagian masyarakat merekomendasikan pembinaan keagamaan ke Taman Pengajian Alquran (TPA) bahkan pesantren.

4. Fungsi perlindungan, mobilitas keluarga yang cukup tinggi dan aktivitas yang padat di perkotaan, sehingga banyak yang merekomendasikan perlindungan anak ke tempat penitipan anak dan lain-lain.

Realitas tersebut menunjukkan bahwa konsep perubahan sosial ekonomi keluarga telah bergeser, banyak yang lebih asyik dengan profesinya masing-masing yang pada akhirnya berimplikasi negatif dengan munculnya ketidakpedulian mereka terhadap perkembangan spiritual, intelektual dan moral anaknya sendiri. Ketika anaknya gagal memenuhi harapannya, maka guru dan institusi pendidikanlah yang disalahkan. Adapun fokus kajian ini pada aspek perilaku pendidik yang berbasis pendidikan Islam sebagai katalisator dari gempuran modernissme, termasuk dalam dunia pendidikan, khususnya di perkotaan. 


\section{PEMBAHASAN}

\section{Pendidikan Islam dan Motivasi Mengajar}

Di lingkungan keluarga, orangtua menjadi garda terdepan dalam pembinaan dan pendidikan anak dan keluarga, Allah Swt. berfirman dalam QS. at-Tahrim (66):6.

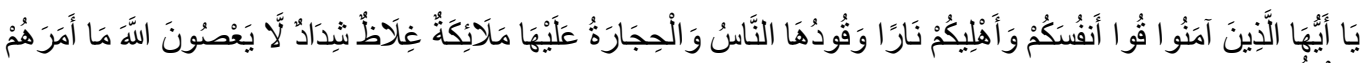

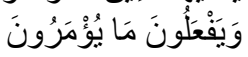

Terjemahanya :

"Hai orang-orang yang beriman, peliharalah dirimu dan keluargamu dari api neraka yang bahan bakarnya adalah manusia dan batu; penjaganya malaikatmalaikat yang kasar, yang keras, yang tidak mendurhakai ( perintah ) Allah terhadap apa yang diperintahkanNya kepada mereka dan selalu mengerjakan apa yang diperintahkan", Q.S. A-Tahrim/66: 6

Makna ayat di atas bahwa sebagai orangtua dan garda terdepan pendidikan di keluarga ditekankan untuk senantiasa menjaga diri dan keluarga dari ancaman modernisasi dan globalisasi di perkotaan. Manusia dan batu disimbolkan sebagai bahan bakar dan ditujukan kepada orang-orang yang tidak menaati perintah dan menjauhi larangan Allah Swt. Dengan realitas tersebut, orangtua harus senantiasa membentengi keluarga dengan pendidikan keagamaan dan jangan ragu untuk memback up anakanaknya sekolah di lembaga pendidikan keagamaan seperti madrasah ataupun pesantren.

Pendidikan berperan menentukan eksistensi dan perkembangan masyarakat, oleh karena pendidikan merupakan usaha melestarikan, dan mengalihkan serta mentransformasikan nilai-nilai kebudayaan dalam segala aspek dan jenisnya kepada generasi penerus. Hawari (1997:155) menekankan bahwa perkembangan anak terjadi menurut suatu pola tertentu yang terdiri dari beberapa tahap, dan beralih dari satu tahap ke tahap berikutnya secara berurutan. Demikian juga Suharsono (2000:3) menguraikan bahwa untuk menjamin agar setiap anak dapat tumbuh dan berkembang sesuai dengan fitrahnya yaitu dengan menjaga masuknya pengaruh luar hingga tersaring baik. Pendidikan dalam bentuk pemeliharaan belum bersifat murni, sebab pendidikan murni diperlukan adanya kematangan psikologis seorang pendidik dan kesadaran mental anak didik.

Manusia diberi potensi besar untuk menata hidupnya menjadi lebih baik dengan berbagai potensi yang dimilikinya, namun seberapa usaha manusia itulah yang menjadi persoalan dasar dalam hidup kesehariannya. Demikian pula dengan peranan Pendidikan Islam yang merupakan salah satu bentuk manisfestasi dari cita-cita hidup ummat Islam 
untuk melestarikan, mengalihkan, menanamkan dan mentransformasikan nilai-nilai Islam tersebut kepada pribadi generasi penerusnya sehingga nilai-nilai kultural-religius yang dicita-citakan dapat tetap berfungsi dan berkembang dalam masyarakat.

Zakiah Daradjat (1980:13) menguraikan bahwa Peranan Pendidikan Islam, yaitu:

1. Pendidikan Islam atau usaha dan bimbingan dan asuhan terhadap anak didik agar kelak setelah selesai pendidikannya dapat memahami dan mengamalkan ajaran Agama Islam serta menjadikan sebagai pelindung hidupnya atau Way of Life.

2. Pendidikan Islam atau pendidikan berdasarkan agama Islam.

3. Pendidikan Islam atau pendidikan dengan melalui ajaran agama Islam, yang berupa bimbingan terhadap anak didik agar nantinya setelah selesai dari pendidikannya ia dapat memahami, menghayati, dan mengamalkan ajaran-ajaran agama Islam yang diyakininya.

Di bagian lain, Zakiah Daradjat (1992:48) menguraikan dalam telaah psikologi, bahwa usia 3-4 tahun dikenal sebagai "masa pembangkan" atau "masa kritis", karena di masa inilah mulai terbuka peluang ke arah kesediaan menerima yang sesungguhnya dan setelah itu anak mulai memiliki "kesadaran" batin atau motivasi dalam perilakunya. Dalam masa perkembangannya, seorang anak yang sedang mengecap pendidikan pasti mempunyai kehidupan yang tidak statis, melainkan dinamis dan pendidikan yang diberikan pada anak haruslah sesuai dengan kejiwaan anak didik pada masa tertentu dalam perkembangannya. Bandingkan dengan pemikiran Zainuddin (1991:106) yang menguraikan pokok-pokok pikiran Al-Gazali yang memandang masa pembinaan dan pembentukan kepribadian itu berlangsung secara berangsur-angsur dan berkembang sebagai proses menuju kesempurnaan.

Perkembangan/pembentukan kepribadian anak tidaklah terjadi dengan begitu saja, melainkan merupakan perpaduan (interaksi) antara faktor-faktor konstitusi biologi, psiko-edukatif, psiko-sosial dan spiritual. Anak akan tumbuh dan berkembang dengan baik bilamana diasuh dan dibesarkan dalam lingkungan keluarga yang sehat dan bahagia, namun bilamana sebaliknya maka anak akan tumbuh dalam ketidakteraturan hidup.

Di sisi lain, Abdullah Nashih Ulwan (1981:81) menguraikan bahwa keteladanan dalam pendidikan merupakan metode influentif yang paling meyakinkan keberhasilannya dalam menyiapkan dan membentuk anak pada moral, spiritual dan sosial. Dalam pandangan kaum terdidik, pendidik yaitu orangtua ataupun guru yang banyak "mewarnai" anak didik tersebut haruslah betul-betul beriman, berilmu pengetahuan untuk menghasilkan output yang berkualitas. 
Selain aspek keteladanan menjadi hal utama pendidikan anak, juga menyangkut tiga hal pokok, yaitu:

1. Aspek kognitif, yaitu kemampuan anak untuk menyerap ilmu pengetahuan yang diajarkan. Hal ini berhubungan dengan kemampuan intelektual dan taraf kecerdasan anak didik.

2. Aspek afektif, yaitu kemampuan anak untuk merasakan dan menghayati apa-apa yang diajarkan, yang telah diperolehnya dari aspek kognitif di atas.

3. Aspek psikomotor, kemampuan anak didik untuk berbuat dan melaksanakan sesuai dengan ilmu yang telah dipelajari (aspek kognitif) dan ilmu yang telah dihayatinya (aspek afektif).

Realitas di masyarakat, khususnya di perkotaan bahwa banyak lulusan perguruan tinggi dan apalagi Perguruan Tinggi berbasis Pendidikan Keagamaan Islam (PTKIs) lulus dengan angka baik (ilmu pengetahuan/ aspek kognitif, namun kurang atau gagal dalam segi afektif dan psikomotornya. Kondisi yang ideal ialah ketiga aspek tersebut harus dijalankan secara integral dan komprehensif, misalnya:

a. Memahami/mengetahui secara intelektual hal ikhwal yang berhubungan dengan shalat (aspek kognitif).

b. Merasakan/menghayati makna serta manfaat dan hikmah shalat baginya (aspek afektif).

c. Melaksanakan amalan shalat secara fisik dengan menjalankan shalat lima waktu (aspek psikomotor).

Pendidikan agama hendaknya dapat mewarnai kepribadian anak, sehingga agama benar-benar manjadi bagian dari pribadinya dikemudian hari. Agar agama dihayati benar dan digunakan sebagai pedoman hidup manusia, maka agama harus menjadi dasar dalam kepribadiannya dan harus diajarkan oleh orang-orang yang dapat bertindak sekaligus pembimbing rohani. Hal utama adalah "penguatan" anak didik dalam keluarga terhadap tiga hal: pertama agar memberi makanan yang halal saja, kedua memberi bekal pendidikan agama dan ketiga memberi bekal pengetahuan keterampilan sebagai bekalnya dalam menjalani hidup di dunia ini. Pendidikan yang berbasis Agama Islam akan menuntun hidup seseorang yang menekankan keseimbangan hidup di dunia yang orientasinya materi dan kehidupan akhirat.

\section{Tanggungjawab Pendidikan}

Pendidikan merupakan suatu kebutuhan primer manusia modern saat ini yang tidak bisa dipungkiri, bahkan semua itu merupakan hak setiap warga negara yang telah 
dijamin oleh hukum dan tentunya mengikat dalam UUD 1945. Pendidikan selalu diarahkan untuk mengembangkan nilai-nilai kehidupan manusia, yang di dalamnya tersirat pengertian manfaat yang ingin dicapai oleh manusia dalam kehidupannya sehingga apa yang ingin dikembangkan merupakan apa yang dapat dimanfaatkan.

Secara kultural, pendidikan pada umumnya berada dalam lingkup peran, fungsi dan tujuan yang tidak berbeda. Hasbullah (1996:5) menegaskan bahwa semuanya hidup dalam upaya yang bermaksud mengangkat dan menegakkan martabat manusia melalui transmisi yang dimiilikinya, terutama dalam bentuk transfer of knowledge dan transfer of values.

Pendidikan dalam arti luas berarti suatu proses untuk mengembangkan semua aspek kepribadian manusia yang mencakup pengetahuannya, nilai, sikap dan keterampilan lainnya. Pendidikan pada hakikatnya akan berusaha untuk mengubah perilaku yang bertujuan agar manusia mencapai kedewasaan atau kepribadian individu yang lebih baik. Perlu dipahami juga, bahwa dengan pendidikan yang maksimal bagi anak maka itu merupakan "investasi" di masa mendatang. Pendidikan berlangsung seumur hidup dan dilaksanakan di dalam lingkungan rumah tangga, sekolah, dan masyarakat. Sehingga pendidikan merupakan tanggung jawab bersama antara keluarga, masyarakat, dan pemerintah.

Allah Swt. menegaskan pula dalam Alquran hal yang relevan dengan uraian di atas, dalam QS.an-Nisa (4): 9.

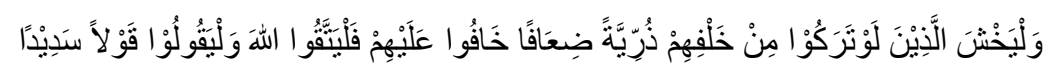

Terjemahnya:

"Dan hendaklah takut kepada Allah orang-orang yang seandainya meninggalkan di belakang mereka anak-anak yang lemah, yang mereka khawatir terhadap kesejahteraan mereka".

Dalam ayat lain ditegaskan pula tentang eksistensi pendidikan, khususnya mendirikan shalat sebagai perisai diri seseorang dalam kehidupan sosialnya di masyarakat. Anak harus dituntun agar mahir mendirikan shalat dan ini merupakan sebuah keharusan bagi orangtua sebagaimana Hadis Nabi tentang tuntutan kepada orangtua menyuruh mengajarkan shalat kepada anak-anaknya yang berbunyi “muruu awlaadakum bisshala...., dan Allah Swt. juga menegaskan hal di atas dalam firmanNya pada QS. 
Luqman (31):17.

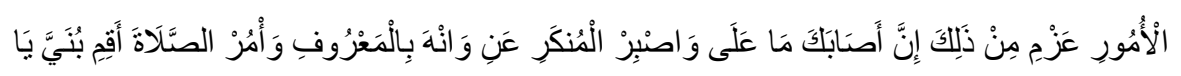

Terjemahnya:

"Hai anakku, dirikanlah shalat dan suruhlah (manusia) mengerjakan yang baik dan cegahlah (mereka) dari perbuatan yang mungkar dan bersabarlah terhadap apa yang menimpa kamu. Sesungguhnya yang demikian itu Termasuk hal-hal yang diwajibkan (oleh Allah)".

Ayat dan ungkapan di atas mengindikasikan akan peran dan tanggung jawab yang begitu besar bagi para pendidik (orangtua) secara khusus, karena anak sebagai "titipan" Tuhan yang harus senantiasa dibekali modal hidup serta pendidikan yang baik dalam mengarungi kehidupan sosial masyarakat. Dengan perhatian yang maksimal dalam masa perkembangannya, termasuk pendidikan berbasis Agama Islam, seperti pembinaan akhlak yang baik, sopan santun, tata cara beribadah yang baik dan benar, sehingga kelak menjadi manusia dewasa yang matang, sopan santun, fisik dan mental yang baik pula.

Daradjat (1992:34) menguraikan bahwa tanggungjawab pendidikan diselenggarakan dengan kewajiban mendidik. Secara umum mendidik ialah membantu anak didik yang dilakukan dalam pergaulan antara pendidik dan anak didik dalam situasi pendidikan yang terdapat dalam lingkungan rumah tangga (orangtua), sekolah (guru), maupun masyarakat (pemimpin dan pemerintah). Pada dasarnya pelaksanaan pendidikan secara aplikatif terbagi kepada dua unsur, yaitu peranan keluarga dalam hal pertumbuhan dan pembentukan sikap awal anak dan yang kedua peranan sekolah sebagai lembaga pengajaran dalam pertumbuhan anak. Selanjutnya H.M. Arifin (1996:10) menekankan bahwa Pendidikan Islam bersumber pada nilai-nilai agama Islam, disamping menanamkan atau memupuk sikap hidup yang dijiwai nilai-nilai tersebut juga mengembangkan kemampuan berilmu pengetahuan sejalan dengan nilai-nilai Islam yang melandasinya merupakan proses ikhtiariah yang secara pedagogis mampu mengembangkan hidup anak didik ke arah kedewasaan yang menguntungkan dirinya. Dengan kata lain Beliau menekankan bahwa pendidikan Islam dimaknai sebagai upaya mempersiapkan individu untuk kehidupan yang lebih sempurna.

Hal utama dalam proses pendidikan adalah persiapan mengajar yang pada hakekatnya merupakan perencanaan jangka pendek untuk memperkirakan atau memproyeksikan tentang apa yang dilakukan. Dengan demikian, persiapan mengajar merupakan upaya untuk memperkirakan tindakan yang akan dilakukan dalam kegiatan pembelajaran, terutama berkaitan dengan pembentukan kompetensi. Dalam 
mengembangan persiapan mengajar, terlebih dahulu harus menguasai secara teoritis dan praktis unsur-unsur yang terdapat dalam persiapan mengajar.

Kemampuan membuat persiapan mengajar merupakan langkah awal yang harus dimiliki guru dan sebagai muara dari segala pengetahuan teori, keterampilan dasar, dan pemahaman yang mendalam tentang obyek belajar dan situasi pembelajaran. Dalam persiapan mengajar harus jelas kompetensi dasar yang akan dikuasai peserta didik, apa yang harus dilakukan, apa yang harus dipelajari, bagaimana mempelajarinya, serta bagaimana pendidik mengetahui bahwa peserta didik telah menguasai kompetensi tertentu. Dalam wordpress.com, E. Mulyasa menyebutkan bahwa guru profesional harus mampu mengembangkan persiapan mengajar yang baik, logis dan sistematis, karena disamping untuk kepentingan pelaksanaan pembelajaran, persiapan mengajar merupakan bentuk dari "profesional accountability". Persiapan mengajar akan membantu pendidik dalam mengorganisasikan materi standar, serta mengantisipasi peserta didik dan masalahmasalah yang mungkin timbul dalam pembelajaran. Persiapan mengajar tersebut dapat berupa apersepsi dosen tentang materi yang akan dipelajari pada pekuliahan tersebut.

\section{KESIMPULAN}

1. Manusia adalah makhluk yang yang senantiasa berupaya untuk maju dan sukses, hendaknya dalam proses ke arah tersebut mengedepankan nilai-nilai Pendidikan Islam dalam semua dimensi sosial kehidupannya dan orangtua yang bertanggungjawab penuh di masa awal pertumbuhan dan perkembangan anak.

2. Pendidikan Islam harus menyentuh tiga institusi pendidikan yaitu keluarga, sekolah dan masyarakat. Jangan dikesankan bahwa tugas pendidikan hanya tugas guru di sekolah ataupun dosen di kampus, bahkan pendidikan keagamaan (tata cara shalat, mandi hadas besar, dan lain-lain) dikesankan tugas ustadz ataupun guru agama di sekolah/kampus.

3. Di sekolah dan perguruan tinggi yang berbasis keagamaan, seperti madrasah dan Universitas Muhammadiyah, jika memungkinkan agar mensinkronkan semua pelajaran umum dengan basic Islam (islamisasi keilmuan) dengan cara menguraikan ayat ataupun hadis yang relevan dengan sub pokok bahasan atau setidaknya dengan mengawali tadarrus.

\section{DAFTAR PUSTAKA}

A Alquran Al-Karim 
Daradjat. Zakiah, (1980) Peranan Agama Dalam Kesehatan Mental, Jakarta: Gunung Agung.

(1992), Ilmu Pendidikan Islam, Jakarta: Bumi Aksara.

H. M. Arifin. M, (1996), Ilmu Pendidikan Islam : Suatu Tinjauan Teoritis dan Praktis Berdasarkan Pendekatan Interdisipliner, Jakarta: Bumi Aksara.

Hasbullah, (1996), Kapita Selekta Pendidikan Islam Di Indonesia, Jakarta: Raja Grafindo.

Hawari. H. Dadang, (1997), Alquran, Ilmu Kedokteran Jiwa dan Kesehatan Jiva (Yogyakarta: Dana Bhakti Prima Yasa.

Suharsono, (2000), Mencerdaskan Anak (Jakarta: Inisiasi Press.

Soekanto, Soejono. (1985), Max Weber: Konsep-konsep Dasar dalam Sosiologi, Jakarta: Rajawali.

Tadjab, (1994), Perbandingan Pendidikan: Studi Perbandingan tentang Beberapa Aspek Pendidikan Barat Moderen, Islam dan Nasional; Surabaya: karya Abditama.

Uhbiyati. Nur dan Abu Ahmadi, (1991), Ilmu Pendidikan, Jakarta: Rineka Cipta.

Ulwan. Abdullah Nashih, Tarbiyatu 'I-Aulad fi 'I-Islam, Juz I \& Juz II, ed. terj. (1981) oleh Drs. Saifullah Kamalie, Lc dan Drs. Hery Noer Ali dengan judul Pedoman Pendidikan Anak Dalam Islam, Semarang: Asy-Syifa'.

UU No. 20 tahun (2003) tentang Sistem Pendidikan Nasional

UU No. 14 tahun (2005) tentang Guru dan Dosen

Usman. Moh. Uzer, (1995). Menjadi Guru Profesional, PT. Remaja Rosda Karya.

Vembriarto. St, (1990), Sosiologi Pendidikan, Yogyakarta: Andi offset

Wirawan. Sarlito, (1982), Pengantar Umum Psikologi, Jakarta; Bulan Bintang.

Zainuddin. (1991), Seluk-beluk, Pendididkan Dari AI-Gazali, Jakarta: Bumi Aksara. 